\title{
"Pulpit power" and the unrelenting voice of Archbishop David Gitari in the democratisation of Kenya, 1986 to 1991
}

\section{Stephen Muoki Joshua and Stephen Asol Kapinde*}

\begin{abstract}
This article sets out to analyse the role of pulpit preaching in the struggle towards the re-emergence of multi-party democracy in Kenya. It argues that through "pulpit power", certain clerics, notably David Gitari, Alexander Muge, Henry Okullu and Timothy Njoya, initiated a process of transformation as individual activists at a time when the state had effectively silenced voices that demanded political change. It then moves on to chronicle David Gitari's sermons as a case in point to demonstrate that his political sermons promoted a culture of defiance in the country and marked the genesis of the so called "second liberation" in Kenya. It relies on archival sources and correspondence material as well as a number of searching in-depth oral interviews.
\end{abstract}

Key words: David Gitari; clergy; Daniel arap Moi; political sermons; democracy in Kenya; activism; Anglican Church.

\section{Opsomming}

Hierdie artikel ontleed die rol van preekstoel-prediking in die stryd om 'n veelpartydemokrasie in Kenia te laat herleef. Daar word aangevoer dat, deur "die mag van die preekstoel", sommige geestelikes, vernaam David Gitari, Alexander Muge, Henry Okullu en Timothy Njoya, as individuele aktiviste 'n proses van verandering teweeggebring het in 'n tyd waarin die staat vir alle praktiese doeleindes daarin geslaag het om stemme wat op politieke verandering aangedring het, stil te maak. Daarop word 'n kroniek van David Gitari se preke gegee om sodoende te wys hoe sy politieke preke 'n kultuur van verset in die land aangewakker het, en die sogenaamde "tweede bevryding" in Kenia ingelui het. Die artikel steun op argivale bronne en korrespondensie, sowel as 'n aantal diepgaande onderhoude.

Sleutelwoorde: David Gitari; geestelikes; Daniel arap Moi; politieke preke; demokrasie in Kenia; aktivisme; Anglikaanse Kerk.

* Stephen Muoki Joshua is a senior lecturer and a chair of the Department of Philosophy and Religious Studies at Pwani University. He is also a research fellow at the University of South Africa. Stephen Asol Kapinde is an adjunct lecturer at Pwani University.

How to cite this article: S.M. Joshua and S.A. Kapinde, "'Pulpit power' and the unrelenting voice of Archbishop David Gitari in the democratisation of Kenya, 1986 to 1991", Historia 61, 2, November 2016, pp 79-100. http://dx.doi.org/10.17159/2309-8392/2016/v61n2a4

Copyright: (CThe Author(s). Published under a Creative Commons Attribution Licence. 


\section{Introduction}

On 22 August 1978, Daniel Torotich arap Moi came to power in Kenya following the demise of the founding father of the nation, Jomo Kenyatta (1963-1978). Moi's formative days in office were quite promising, especially with the release of political detainees. ${ }^{1}$ Early in his first term in office, President Moi, a Kalenjin by ethnic group, called for peace, love and unity. This call was well received by most Church leaders because they felt that it was in keeping with Christian principles. ${ }^{2}$ It is on this basis that the Church, via the National Church Council of Kenya (NCCK) under David Gitari as the chairman, became involved in certain state activities that were aimed at poverty alleviation and the integration of the various Kenyan communities. ${ }^{3}$ This cooperation, which was only witnessed during the nascent days of Moi's rule, commenced in 1978 when the NCCK formed a committee chaired by Gitari to look into the biblical relevance of nyayo philosophy. ${ }^{4}$ Later, NCCK operated like any other state department, in other words, it lacked a critical voice that was in a position to raise the alarm over state malpractices that were emerging day by day, such as the "Kalenjinisation" 5 of the military and the civil service. ${ }^{6}$ Changes such as this were made because Moi had inherited a civil service, military and other professional bodies that were predominantly composed of officials from the Agikuyu ethnic community. ${ }^{7}$

In his consolidation of power, although Kenya had been a de facto one party state for some time, Moi felt that growing opposition, mainly from the Agikuyu power

1. B.A. Ogot, "Transition from Single-Party to Multi-Party Political Systems", in B.A. Ogot and W. Ochieng (eds), Decolonization and Independence in Kenya, 1940-1993 (Ohio University Press, Athens, 1995), pp 239-261.

2. Interview (digital recording) with J.S. Mathenge, conducted by S. Kapinde, Nairobi, 29 January 2015.

3. Interview with Mathenge, conducted by Kapinde, Nairobi, 29 January 2015.

4. D.W. Throup and C. Hornsby, Multi-Party Politics in Kenya: The Kenyatta and Moi States and the Triumph of the System in the 1992 Election (James Currey, Oxford, 1998), p 20. See also G.G. Githiga, The Church as the Bulwark against Authoritarianism (Regnum, Oxford, 2001), p 69. He contended that between 1978 and1985, the relationship between Moi and the Church was very cordial. It is as if Moi had "hijacked the pulpit" in order to give the impression of being a Christian leader.

5. K.G. Adar and I.M. Munyae, "Human Rights Abuse in Kenya under Daniel arap Moi 1978-2001", African Studies Quarterly, 5, 1 (2001), available online at http://web.africa.ufl.edu/asq/v5/v5i1a1.htm have observed that Moi focused on the gradual "Kalenjinization" and "de-Agikuyu-nization" of public and private sectors from the 1980s. This was evident in state appointments, where people of Kalenjin ethnic origin were given key posts in parastatals such as the Agricultural Development Corporation (ADC); the Kenya Commercial Bank (KCB); Kenya Post and Telecommunications (KPT); the Central Bank of Kenya (CBK); Kenya Industrial Estates (KIE); the National Cereals and Produce Board (NCPB); and the Kenya Grain Growers Cooperative Union (KGGCU).

6. Adar and Munyae, "Human Rights Abuse in Kenya under Daniel Arap Moi".

7. Throup and Hornsby, Multi-Party Politics in Kenya, p 26. 
elites and Luo community, was a threat to the establishment. ${ }^{8}$ On 9 June 1982, the Kenya African National Union (KANU) rushed through an amendment to the constitution that made Kenya a de jure one-party state, thereby criminalising the formation of any political party to rival KANU. The urgency of this step was compounded by the fact that Jaramogi Oginga Odinga and George Moseti Anyona, aware that Kenya was still a de facto single-party state, were planning to register a new political outfit, to be named the Kenya Socialist Alliance in June $1982 .{ }^{9}$ In the long run, Moi perpetuated corruption, oppression of political competitors and any prochange elements, while at the same time flirting with mass line populism under the guise of nyayo, ${ }^{10}$ thereby entrenching political patronage in a manner similar to that of his predecessor, Jomo Kenyatta. ${ }^{11}$

Consequently, an attempted coup d'état was organised on 1 August 1982 by junior Kenya Air Force (KAF) officers drawn mainly from the Luo and Agikuyu ethnic community..$^{12}$ They challenged the officialdom of Moi and put his legitimacy as the head of state to the test. ${ }^{13}$ According to Throup and Hornsby:

The motivation behind this coup is very obscure, but the dissatisfaction of the Agikuyu power elites with Moi and the political alienation of the Luo community by the Kenyatta and Moi regimes seem to have been the main impetus which drove the two ethnic political adversaries to converge in an attempt to oust the incumbent. ${ }^{14}$

It appears that political opportunity rather than ideological issues were behind the coup. However, many commentators place the reasons for the failed coup on the deteriorating economic situation; the politics of clientilism; state unaccountability; and human rights abuses. The aftermath of the coup was disastrous - it led to total disorder, provoking several days of political upheavals and unrest throughout the country, although these were largely spontaneous in nature. ${ }^{15}$

8. Ogot, "Transition from Single-Party to Multi-Party Political Systems", pp 239-261.

9. W.O. Oyugi, "Uneasy Alliance: Party-State Relations in Kenya", in W.O. Oyugi (ed.), Politics and Administration in East Africa (East African Educational Publishers, Nairobi, 1994) pp 153-191.

10. The word nyayo is a Kiswahili word meaning a footstep. Moi literally employed the word as reference to the pattern of leadership of his predecessor.

11. K. Currie and L. Ray, "State and Class in Kenya: Notes on the Cohesion of the Ruling Class", The Journal of Modern African Studies, 22, 4 (1984), pp 559-593.

12. For biographical detail on the masterminds behind the coup on 1 August 1982 and their ethnic inclination, refer to W. Gichere, "A Gallery of Rebels", Weekly Review, 22 October 1982.

13. Throup and Hornsby, Multi-Party Politics in Kenya, $\mathrm{p} 31$.

14. Throup and Hornsby, Multi-Party Politics in Kenya, p 31.

15. G. Sabar-Friedman, “'Politics' and 'Power' in the Kenyan Public Discourse and Recent Events: The Church of the Province of Kenya", Canadian Journal of African Studies, 29, 3 (1995), pp 429-453. Online at http://www.jstor.org/stable/486017 Accessed on 6 November 2014. 
Galia Sabar is in agreement with Throup and Hornsby that the coup attempt awakened the state and transformed Kenya's political landscape. ${ }^{16}$ She observes:

Moi embarked on a coercive centralizing process like his predecessor that entailed the curtailing of free expression in parliament and the limiting of the autonomy and independence of the judiciary. ${ }^{17}$

She further argues that political persecution as well as the criminalisation of opposition groups and restrictions placed on political gatherings were moves calculated to strengthen the de jure one-party state. ${ }^{18}$ What followed was limitations placed on the activities of professionals, including student and academic unions, ethnic groups and religious organisations. ${ }^{19}$ Simply put, alternate political voices were mercilessly suppressed. ${ }^{20}$ Under such conditions, the true ideals of nyayoism as captured by Gitari and others in their work on the "biblical relevance of nyayo" were compromised.

In an interview which Stephen Kapinde conducted with Ephantus Muriuki, an Anglican priest who served in Mount Kenya East diocese in the 1980s, Muriuki succinctly observed that true love, unity and peace evaporated into political hatred, disunity and betrayal, making Moi out to be the main pillar of nyayo philosophy. ${ }^{21}$ Similarly, Franz Fanon contended that "single party states ... [are] nothing but the name, the emblem, and motto and they ... [are] used to immobilise the people and become a means for self-advancement". ${ }^{22}$ Joseph Ng'awatha, a political analyst who was also interviewed, summarised this self-advancement when he noted that "Moi earned the infamous slogan nyayo and nyayo became synonymous to Moi - a clear sign of personalisation of power and centralisation of the presidency under a oneparty system." ${ }^{23}$ Indeed, this was a fulfilment of Henry Okullu's ${ }^{24}$ earlier warning that:

Politically most African states were ruled by military dictators with every individual's life expendable at any time the ruler may decide ... Powerful bureaucracies rule the few remaining states. Leadership is personalized and this

16. Throup and Hornsby, Multi-Party Politics in Kenya, $\mathrm{p} 31$.

17. Sabar-Friedman, "Politics and Power", p 432.

18. Sabar-Friedman, "Politics and Power", p 432.

19. Sabar-Friedman, "Politics and Power", p 432.

20. M. Amutabi, "Beyond Imperial Presidency in Kenya: Interrogating the Kenyatta, Moi and Kibaki Regimes and Implications for Democracy and Development", Kenya Studies Review, 1 (2009), pp 55-84.

21. Interview (digital recording) with Ephantus Muriuki conducted by Stephen Kapinde, at St. Thomas Cathedral, Kirinyaga, 30 January 2015.

22. J. Mati, "The Power and Limits of Social Movements in Promoting Political and Constitutional Change: The Case of the Ufungamano Initiative in Kenya (1999-2005), $\mathrm{PhD}$ thesis, University of the Witwatersrand, 2012.

23. Informal interview with J. Ng'awatha, conducted by Stephen Kapinde, Msumarini Secondary School, Kilifi, Kenya, 24 March 2015.

24. Henry Okullu was an Anglican bishop in the diocese of Maseno West, Kenya, from 1980 to 1997. 
personalization leads to idolization of the leader to such an extent that people are made to believe that their rights come from the generosity of that leader. ${ }^{25}$

Okullu illuminated this trend of personalisation further by arguing that "power is sought and maintained, often by unjust means, for its own sake". As a result of this, he goes on to say, Africa is involuntarily experimenting with something new, a system of government which can best be described as one-party dictatorship. ${ }^{26}$ In this line of interpretation, David Kodia said that a system such as this nullified all possibility of having an accountable government in Africa. ${ }^{27}$ It is indeed an antidote to democratisation in Africa.

Okullu and Kodia's observations have also not escaped the writings of O'Donovan that have spelt out the general character of political leaders in modern Africa as follows. He is more often than not:

\begin{abstract}
...a big man who looks like this. His face is on the money. His photograph hangs in every office in his realm. He names streets, football stadiums, hospitals and universities after himself. He insists on being called "doctor" or "... the big elephant" or ... "the wise old man, or the national miracle". His every pronouncement is reported on the front page... He scapegoats minorities to shore up support. He rigs elections. He emasculates court justice. He cows the press. His enemies are detained or exiled, humiliated or bankrupted, tortured or killed. He uses the resources of the state to feed a cult of personality and defines himself as incorruptible, all knowing ... and kind to children. His cult equates his personal well-being with the wellbeing of the state. ${ }^{28}$
\end{abstract}

O'Donovan's observation is married to the assertion by Kodias that the common denominator between African dictators and advocates of a single-party system is being praised like gods on earth. ${ }^{29}$ Moi, in particular, perfected this feature with songs being composed in his honour. ${ }^{30}$ Such songs were termed "patriotic" and

25. “Okullu: The Dissenting Patriot", The Weekly Review, 18 July 1977.

26. J. Oluoch, The Christian Political Theology of Rt. Rev. Dr John Henry Okullu, Bishop of the Diocese of Maseno South of the Anglican Church of Kenya (1929-1999)(Regnum, Oxford, 2003).

27. D. Kodia, "The Role of the Church in the Democratization Process in Kenya", International Journal of Innovative Research \& Development, 3, 5 (2014), pp 64-69. Online at www.ijird.com

28. W. O'Donovan, Biblical Christianity in Modern Africa (Paternoster Press, Milton Keynes, 2000). See also similar remarks by Paul Gifford at a symposium on "Problems and Promises for Mission: Africa Beyond 2000", organised by the All Africa Conference of Churches in Mombasa, Kenya. Paul Gifford describes an African leader as the "Big Man" whose remarks have the power of the law. Indeed, he is the law.

29. Kodia, "The Role of the Church in the Democratization Process in Kenya", pp 64-69.

30. Songs such as "Tawala Kenya" was consciously or unconsciously composed to disguise the real President Moi and bless his despotic rule out of fear. In addition, a loyalty pledge was crafted to indoctrinate the young minds in schools and style it as patriotism. It became a norm that after singing the national anthem, learners had to 
healthy for national cohesion. ${ }^{31}$ Using African metaphor, Kodia referred to African leaders as "the only cock that could crow", the inference being that other mature cocks were clamped down by unorthodox means. ${ }^{32}$

With a crackdown on dissidence and the limited political space characterised by detention of opposition politicians; arrest and harassment of journalists and academics; and a clampdown on political associations or debates (except those for the glorification of Moi and the presidency) there were many schools, streets, stadiums and airports named after him. Moi explicitly qualified O'Donovan's description of "presidential cult-dom". 33 There was an environment of fear and it became nearly impossible to set any social movement against the state. ${ }^{34}$ Galia Sabar observed that limited political association paralysed the process of transforming information and ideas into action. ${ }^{35}$ This gave credence to the rise of informal individual activism and the culture of defiance that was growing day by day.

In the frontline of individual Church activism were Rev. Henry Okullu who served as the bishop of the Maseno South Diocese of the Anglican Church; Rev. Alexander Muge, an outspoken Anglican bishop of Eldoret diocese, who was assassinated in 1990; Rev. David Gitari, the Anglican prelate of Mt. Kenya East diocese; and Rev. Timothy Njoya, a moderator in the Presbyterian Church of East Africa (PCEA), who was later demoted by the Church leadership due to his unrelenting criticism of the state. This "quartet" was commonly referred to by politicians, as "a

recite the "loyalty pledge" as follows: "I pledge my loyalty to the President and Nation of Kenya; my readiness and duty to defend the flag of our Republic; my life, strength and service in the task of nation-building and in the living spirit embodied in our National motto 'Harambee' and perpetuated in the Nyayo philosophy of Peace, Love and Unity". Henceforth, it evolved into a memorised verse that could not escape the attention of any Kenyan citizen who was going through the 8-4-4 Education System. For more on political indoctrination by the state, see D. Moi, Kenyan African Nationalism, Nyayo Philosophy and Principles (Macmillan, London, 1986).

31. Kodia, "Role of the Church in the Democratization Process", pp 64-69.

32. Kodia, "Role of the Church in the Democratization Process, pp 64-69.

33. Some of the places named after Moi include Moi Avenue; Moi International Airport (Mombasa); Moi Sports Centre, Kasarani (Nairobi); Moi Teaching and Referral Hospital, (Eldoret); and numerous other schools countrywide. His political philosophy (Nyayo) also became a brand name for products and other activities initiated by the government, such as Maziwa ya Nyayo (nyayo milk); the Nyayo Tea Zone; and Nyayo wards (in public hospitals).There was also a Nyayo Stadium and Nyayo cars (which did not take to the roads because the project collapsed).This cult-like image characterised the Moi regime. His portrait hung on the walls of business premises and his image was emblazoned on Kenyan currency. Furthermore, his birthday, 10 October, was celebrated as an official holiday in Kenya, although it has now been scrapped by the NARC regime.

34. R. Press, "Establishing a Culture of Resistance: The Struggle for Human Rights and Democracy in Authoritarian Kenya, 1987-2000", PhD thesis, University of Florida, 2004.

35. Sabar-Friedman, "Politics and Power", p. 433. 
thorn in the flesh" to Moi and his political ilk.36 In her study, Galia Sabar gives credence to the Anglican Church (formerly the Church of the Province of Kenya) as the architect of a reform agenda in Kenya. Sabar's work was based on her wide network and financial independence. ${ }^{37} \mathrm{But}$ at the same time, she also gave attention to the three Anglican clergy within the reform train alongside Rev. Timothy Njoya of PCEA. In her writings, she painted a picture of the clergy as playing a secondary role in the struggle, contrary to other findings that locate the individual clergy as the primary driving force of the game of change. ${ }^{38}$ However, her perspective is of great significance considering the historical context under which these clergy were emerging as voices of reason and the Church as a shelter of immunity against state backlash.

The involvement of the clergy in political discourses was largely motivated by the absence of opposition parties and the crackdown on dissidents, which was marked by severe state surveillance and censorship. ${ }^{39}$ Therefore the Church and semiprofessional bodies such as the Law Society of Kenya (LSK), became the only independent institution(s) that could speak out against state malpractices. ${ }^{40}$ Galia Sabar, while invoking the importance of the Church as an independent institution said:

from then on, the churches, and especially the Church Province of Kenya (CPK), became one of the few remaining channels to express discontent and the desire for change in the country. Furthermore, the opportunity for the clergy to speak freely to their congregations and the possibility for CPK members to exchange views within the physical shelter of the Church thus acquired grand strategic significance. ${ }^{41}$

This article narrows down the discussion to a single cleric, the Rev. David Gitari and attempts an analysis of his sermons and their influence in motivating democratic space in Kenya during the period under review.

\section{Pulpit power and David Gitari}

On 18 May 1987, the then president, Daniel arap Moi, announced that the registration of voters was to commence on 15 June 1987 and that only members with identification cards and KANU membership cards would be allowed to vote. ${ }^{42}$ This state declaration did not go down well with Gitari, as observed by Ephantus Muriuki, John Mararo and John Kangangi in an interview with the two authors of this article. ${ }^{43}$

36. Throup and Hornsby, Multi-Party Politics in Kenya, p 55.

37. Sabar-Friedman, "Politics and Power", pp 429-453.

38. Sabar-Friedman, "Politics and Power", pp 429-453.

39. Interview with J.S Mathenge conducted by S. Kapinde, Nairobi, 29 January 2015.

40. Throup and Hornsby, Multi-Party Politics in Kenya, p 55.

41. Sabar-Friedman, "Politics and Power", pp 429-453.

42. See "Moi Sets Date for Registration of Voters", Daily Nation 19 May 1987.

43. Interview (digital recording) with Ephantus Muriuki, John Mararo and John Kangangi, conducted by the authors, at St. Thomas Cathedral, Kirinyaga, 30 January 2015. 
According to Gitari, the state had flagrantly violated the constitution. This move, he said, was a contravention of section 43 of the (former) constitution which laid down the qualification and disqualifications for registration as a voter. The 1987 declaration disenfranchised a huge chunk of voters. ${ }^{44}$ To prove his case, Gitari delivered a sermon titled "Harassed and Helpless" - an exposition based on Matthew 9:35-38 which reads:

And Jesus went about all the cities and villages, teaching in their synagogues, and preaching the gospel of the kingdom, and healing every disease and every infirmity. When he saw the crowds, he had compassion for them, because they were harassed and helpless, like sheep without a shepherd. Then he said to his disciples the harvest is plentiful, but the labourers are few; pray therefore the Lord of the harvest to send out labourers into his harvest. 45

In his hermeneutics, the prelate claimed that the citizens of Kenya were harassed like sheep without a shepherd because they were being blocked from exercising their democratic right. ${ }^{46}$ In this sermon, Gitari addressed a number of issues, ranging from corruption in the Kenya Planters Cooperative Union (KPCU), to economic inflation, to politics. ${ }^{47}$ But of utmost significance was his call for the constitution to be upheld, because it guaranteed that all citizens who qualified constitutionally to register as voters were able to do so regardless of any membership fee. ${ }^{48}$ In moments of crisis, he said, it was often difficult to get leaders who could rise to the occasion to stand with the poor.

Gitari referred to Jesus's words that "the harvest is plentiful but the labourers are few". In this dramatic sermon, Gitari challenged the clergy on their moral and pastoral duties as the shepherds of the flock. He went on to say: "In our ministry to the people of the Ndia Division or Archdeaconry, we must follow in the nyayo [footsteps] of Jesus Christ." 49 According to Greenman, this was a direct challenge to Moi's new philosophy and a biblical critique of nyayo, because Gitari had laid the "centrality of justice as the firm foundation for peace, love and unity." 50 Theologically, Gitari's call for people to follow the nyayo of Jesus was (is) in line with the doctrine of incarnation, which is the common modus operandi in his socio-political engagement. Gitari observed: "To tell us not to be involved in the welfare of our country is virtually to tell us not to follow the example of Jesus Christ". ${ }^{51} \mathrm{He}$ argued further that "Jesus

44. Interview with Muriuki, Mararo and Kangangi, conducted by the authors, St. Thomas Cathedral, Kirinyaga, 30 January 2015.

45. African Living Bible, see Matthew 9:35-38.

46. D.M. Gitari, Let the Bishop Speak (Uzima Press, Nairobi, 1988), pp 13-14.

47. Gitari, Let the Bishop Speak, $\mathrm{p} 15$.

48. Gitari, Let the Bishop Speak, $\mathrm{p} 16$.

49. Gitari, Let the Bishop Speak, 10.

50. J. Greenman, "Anglican Evangelicals on Personal and Social Ethics", Anglican Theological Review, 94, 2 (2012), pp 179-205, 201.

51. D.M. Gitari, "Church and Politics in Kenya", Transformation, 8, 3, (July/September 1991), p 10. 
assumed human form and took up residence in this world and He prepared to take part as a perfect human being in every sphere of life with hope of bringing salvation to the world". 52 This is seconded by Eunice Kamara in her article when she argues that "Christ is the perfect model of the Church and therefore Christians must follow in His footsteps [nyayo]". 53

On election, Gitari urged the people to go out in large numbers and elect leaders of their choice and he also requested the clergy to be vigilant throughout the exercise. ${ }^{54}$ He said: "Do not stay at home, but go and see for yourself how this exercise will be carried out, and urge the people to register." 55 It is evident, therefore, that this was a call for direct social engagement of the individual clergy. Gitari encouraged his pastors to find out why people were harassed and helpless, and to have compassion on them. According to J.N.K. Mugambi, the mission of Christ is twofold: to liberate humankind on the socio-political and economic sphere and to lead them to salvation on the eschatological plane. ${ }^{56}$

Suffice it to say that nyayoism might well have been a good state philosophy based on the previous study by Gitari and others, ${ }^{57}$ but its chief proponents in the Kirinyaga region of Kenya, as elsewhere in the country, had no clear understanding of its roots and manifesto. To them, as claimed by Ephantus Muriuki, nyayo meant to follow the footsteps of Moi, whereas the true meaning was to follow Christ, the symbol of justice and the icon of peace, love and unity. ${ }^{58}$ Based on this blindfold blessing of the state, Ogot attested that "to be anti-nyayo was to be anti-government, a further entrenchment of the political monolithism which had been introduced under Kenyatta".59

Two weeks later (21 June 1987), during a civic service at St. Peter's Nyeri, following an invitation by the then Bishop of Mt. Kenya Central, Rt. Rev. John Mahianini, Gitari called for the democratisation of the country. The sermon was

52. Gitari, "Church and Politics in Kenya", p 10.

53. E. Kamaara, "Religion and Socio-Political Change in Kenya, 1978-2003", in J.N.K. Mugambi and F. Kürschner-Pelkann (eds), Church-State Relations: A Challenge for African Christianity (Acton, Nairobi, 2004), pp 125-137.

54. By telling the people to elect leaders of their choice, Gitari was touching on a key component of democracy where people agree to be governed by a popularly elected leader.

55. Gitari, Let the Bishop Speak, $\mathrm{p} 16$.

56. J.N.K. Mugambi, African Christian Theology: A Definition (Heinemann, Nairobi, 1989), p1.

57. National Church Council of Kenya, A Christian View of Politics in Kenya: Love, Peace, and Unity (Uzima Press, Nairobi, 1983).

58. Interview with Muriuki conducted by Kapinde, St. Thomas Cathedral, Kirinyaga, 30 January 2015.

59. Ogot, "Transition from Single-Party to Multi-Party Political Systems”, p 243. 
entitled "The Truth is Always Triumphant" ${ }^{60}$ This was the most widely publicised and cited political sermon of the time. In his address, Gitari expounded on the book of Daniel, chapter 6.He drew explicitly on the context under which Daniel - a faithful servant of God - was mistreated by conniving workmates in Persia. ${ }^{61}$ The conspiracy was hatched in order to block him from ascending to a higher position of power. Gitari summarised his political sermon by calling all leaders to stand by the truth, even if they faced stiff opposition. This was in line with his prophetic vision and also congruent to the evangelical tradition, when he said that "social witness begins with personal morality". 62 Thomas Wright, as cited in Greenman, elucidates our thinking on personal morality further by writing that: "Christian moral growth is a matter of looking away from oneself and towards God on the one hand and one's neighbour on the other."63

On these occasions, Gitari's sermons were termed by some politicians as provocative, destructive criticism, bordering on subversion and treason and above all, an abuse of the freedom of worship. ${ }^{64}$ Reacting to Gitari's sermon, the then KANU national chairman, Okiki David Amayo claimed that the prelate was seeking to destabilise the country by creating chaos through public incitement. ${ }^{65}$ Furthermore, he claimed that Gitari's biblical reference to Daniel chapter 6 (about Darius and Daniel) had no parallel in Kenya. ${ }^{66}$ Consequently, he opined, such references could only be made with the aim of confusing God-fearing and peace-loving Kenyans. ${ }^{67}$ For his part, Burundi Nabwera, the secretary general of KANU, warned the clergy against misusing the pulpit. ${ }^{68} \mathrm{He}$ lamented:

What is going on today, really? While some of the markedly well-educated Kenyan clerics in the 'protestant fold' are globe-trotting, others have been politicking from the pulpit or in the open air, feigning constitutional immunity. ${ }^{69}$

Similar sentiments were echoed by Kirinyaga KANU branch organising secretary, Gichinga Muchine, who cautioned Gitari against turning the churches in the district into a political forum. ${ }^{70}$

60. D.M. Gitari, Troubled, but Not Destroyed: An Autobiography of Dr David M. Gitari, Retired Archbishop of the Anglican Church of Kenya (Isaac Nathan Publishing; 2014), pp 215-216.

61. Gitari, Troubled, but Not Destroyed, $\mathrm{p} 215$.

62. Gitari, Let the Bishop Speak, pp 32-38.

63. N. Wright, After You Believe: Why Christian Character Matters (HarperOne, New York, 2010), p 204.

64. "Minister Attacks Bishop", Daily Nation, 24 June 1987.

65. Gitari, Let the Bishop Speak, $\mathrm{p} 40$.

66. Gitari, Let the Bishop Speak, $\mathrm{p} 40$.

67. "KANU Replies to Gitari's Sermon", Daily Nation, 27 June 1987.

68. "Misusing the Pulpit", Kenya Times, 15 June 1987.

69. Burundi Nabwera (KANU's secretary general), as quoted by Gitari, Let the Bishop Speak, p 31. See also "Misusing the Pulpit", Kenya Times, 15 June 1987.

70. "Party Branch Now Hits out at Bishop", Kenya Times,10 June 1987. 
Reading from the same scripts, President Moi observed:

I expect the Church to pray for the weak. If the Church's objective is to sympathise with the oppressors, referring to Kenya Planters Co-operative Union (KPCU), then there must be something brewing. ${ }^{71}$

He continued in similar vein:“KPCU must be reformed through an amendment of its old constitution to cater for the interest of farmers. The bishop [Gitari] now asks that we pray for the oppressors - Mungu aturehemu [God have mercy on us]."72

A similar trend of attacks and a barrage of condemnation appeared in the daily newspapers throughout the month, all responding to various issues raised by Bishop Gitari in his sermons..$^{73}$ Some called for an apology from Gitari; ${ }^{74}$ or felt that he should face disciplinary action for inciting peace-loving Kenyans. And if needs be, they said, should even be banished from Kenya. ${ }^{75}$ Others requested the Church of the Province of Kenya (CPK) to disown Gitari for his irresponsible antics and critical statements about the state. ${ }^{76}$ But was it possible to "disown" David Gitari? As John Mararo observed in an interview, it is true that Gitari could have been disowned by his own people as well as the Church, but this was unlikely because his message was clear and reflected the frustrations that the people were facing at the time. ${ }^{77}$

The attack on Gitari was compounded by the fact that some political and Church leaders felt that he was misusing the pulpit. On many occasions, they insisted that the Church should confine itself to spiritual matters. Some even declared that outspoken Church leaders should not use the pulpit for their political utterances, but should rather leave politics to politicians or resign their posts and join active politics. ${ }^{78}$ Others went further to (mis)interpret Romans 13 by arguing that Church leaders should not challenge the state since all leadership is ordained by God. Nonetheless, in his defence on 28 June 1987 against backlash from the political fold at Good Samaritan Church (Kathiga), Gitari launched a spirited riposte using the scripture 2 Timothy 3:16 to 2 Timothy $4: 7$

71. “KPCU: Moi Hits Out at Bishop”, Standard Newspaper, 9 June 1987.

72. "KPCU: Moi Hits Out at Bishop", Standard Newspaper, 9 June 1987.

73. Interview with Muriuki, conducted by Kapinde, St. Thomas Cathedral, Kirinyaga, 30 January 2015.

74. See the press conference held by Mr Ngumbu Njururi (an assistant minister in the office of the president) on 23 June 1987. The story is well captured in "Bishop Criticised over Remarks", Standard Newspaper, 24 June 1987. See also "Minister Attacks Bishop", Daily Nation, 24 June 1987, for similar sentiments.

75. Mr Peter Ejore (an assistant minister for Co-operative Development) called for KANU to discipline Gitari, alleging he was "serving his foreign masters and not God". See "Gitari: KANU Action Urged", Kenya Times, 1 July1987.

76. See Editorial, “CPK Should Disown Gitari's Antics”, Kenya Times, 29 June1987.

77. Interview with John Mararo, conducted by Stephen Kapinde,30 January 2015.

78. D.M. Gitari, Responsible Church Leadership (Acton Publishers, Nairobi, 2005), p 155. 
All scripture is inspired by God and profitable for teaching, for reproof, for correction, and for training in righteousness, that man of God may be complete, equipped for every good work. ${ }^{79}$

In this exposition, Gitari responded directly to David Okiki Amayo who had claimed that the biblical reference to the book of Daniel 6 had no parallel in Kenya. Gitari said; “ ... we are being told that Daniel 6 is not applicable to the modern man in Kenya...Has Kanu the right to tell Church leaders which passages in the Bible are profitable to Kenya or which are not profitable?" 80 According to Gitari, all scriptures are inspired by God, including Daniel chapter 6, hence the scriptures can be utilised for expounding on the truth, rebuking error, correcting faults and for our training in the ways of righteousness. ${ }^{81}$

The centrality of the scripture as authoritative, as was articulated by Gitari, is a common strand of evangelical Anglicans, and forms part of their theological heritage. On this, Greenman observed that:

... the unshakable biblicism and conversionism of this strand of Anglicanism, the task of Christian ethics is to discern the meaning of the gospel's call to personal transformation in becoming like Christ and to probe from a biblical standpoint the full range of questions about moral, social, and political life ...Not only is scripture the supreme authority in all matters of faith and conduct, but additionally, biblical preaching and teachings are the foremost means of authentic ministry. ${ }^{82}$

Greenman's voice on the centrality of the Bible is not alone, because Sanneh, Mbiti and even Kenyan literary icon, Ngugi Wa Thiong'o, have appreciated the centrality of the Bible in African Christianity and politics. ${ }^{83}$ Ngugi, although an avowed atheist, admitted that his writings cannot escape biblical imagery and metaphors if he is to be relevant to his Kenyan audiences. ${ }^{84}$ This therefore gives credence to the notion of "pulpit power". Church leaders cannot cut themselves off from the rest of society, and in an environment where voices of dissent have been stifled, the clergy can utilise the pulpit for social transformation of society.

The pulpit as used in this research is not confined to a structure or building; a pulpit can be any platform at all, where the clergy are able to contribute to critical, constructive and creative interaction, including the process of social transformation.

79. Gitari, Troubled, but Not Destroyed, p 223.

80. Gitari, Let the Bishop Speak, p 46.

81. Gitari, Let the Bishop Speak p 46.

82. Greenman, "Anglican Evangelicals on Personal and Social Ethics”, pp 204-205.

83. L. Sanneh, Translating the Message: The Missionary Impact on Culture (Orbis Books, Maryknoll, 1989). See also J. Mbiti, "Do you Understand What you are Reading? The Bible in African Homes, Schools and Churches”, Missionalia,33, 2 (2005), pp 205-213.

84. J. Lonsdale, "Religion and Politics in Kenya", Lecture delivered at Trinity College, Cambridge, 2004. See http://www.martynmission.cam.ac.uk/CJLonsdale.html 
While the approach to this mission may vary from one place to another according to the demands of the specific context or society, the mission and the object remain the same. ${ }^{85}$ In pulpit power, the Bible is regarded by the Church as one of the most powerful and influential tools for civic education. David Gitari, in his critique of the government,

employed biblical metaphors, episodes, and narratives, all aimed at showing how in the confrontation between the powerful and the powerless, God himself chooses the side of the latter, thus protecting the rights of the victim against corruption and the abuse of power. ${ }^{86}$

Gathogo correctly observed that Gitari respected the Bible as authoritative and transformational. In 1991 the prelate rebuked the Kirinyaga County Council for having facilitated the grabbing of Kamuruana Hill -a publicly-owned property - by two local politicians. Gitari went to the nearby Mutuma Trinity Church and based his sermon on 1 Kings 21:1-29 as a relevant text, asking his congregation rhetorically: "Was there no Naboth to say 'no'?"87 This view of God as a saviour of the poor and powerless in the wake of oppression, is centred on a liberation framework as a way of articulating African theologies in precolonial and postcolonial times. ${ }^{88}$

David Gitari is vindicated by the scripture in what Greenman referred to as prophetic Biblicism. ${ }^{89}$ As for Gitari, he stood by what he had said. Similarly, Martin Luther, the father of the Reformation, at his trial at the Imperial Court at Worms (1521) declined to apologise as demanded by some leaders. Gitari said:

Unless I am convicted by the scriptures and plain reason, my conscience is captive to the word of God. I cannot and will not recant anything, for to go against my conscience is neither right nor safe. Here I stand: God help me..$^{90}$

Having stood his ground, Gitari alluded to his suffering for the sake of the gospel and the people, but vowed to soldier on, to continue his endeavours come what may: "... woe unto me if I do not preach the gospel!" ${ }^{11}$ As observed by one of the interviewees, this declaration was a warning to his political detractors that aluta continua (the struggle continues). ${ }^{92}$

85. Kamaara, "Religion and Socio-Political Change in Kenya", pp 125-137.

86. J.M. Gathogo, Mutira Mission: An African Church Comes of Age in Kirinyaga, Kenya (1912-2012) (Zapf Chancery Publishers, Limuru, 2011), p 133.

87. D.M. Gitari, In Season and out of Season: Sermons to a Nation (Regnum, London, 1996), p 16.

88. G. Gutierrez, The Power of the Poor in History (Orbis Books, Maryknoll, 1983), p 27.

89. Greenman, "Anglican Evangelicals on Personal and Social Ethics", pp 179-205.

90. Gitari, Let the Bishop Speak, p 50.

91. Gitari, Let the Bishop Speak, p 50.

92. Interview with Muriuki, Mararo and Kangangi, conducted by the authors, St. Thomas Cathedral, Kirinyaga, 30 January 2015. 
Following Gitari's unrelenting voice, many other individual Church leaders consistently condemned the continued one-party dictatorship. In particular, Bishop Alexander Kipsang Muge and Timothy Njoya were buoyed by Gitari's political sermons and began to challenge Moi's leadership style. In a choreographed move to delegitimise the regime, Rev. Timothy Njoya predicted the fall of nyayo. He likened the Kenyan experience to the transformation in Eastern Europe. ${ }^{93}$ Many other Church leaders elsewhere in the country made similar remarks. This pulpit preaching and the need for social transformation were marked by huge prayer rallies popularly known as crusades in the countryside, and well attended Church services were also held in the urban areas. Consequently, on 30 June 1987 at the State House in Nairobi, Moi bowed to pressure and stopped his henchmen from the spate of attacks made on the prelate. He declared: "Let the bishop speak."

Bishop David Gitari of the CPK should be allowed to speak his mind as Kenya is a democratic country. However, the Anglican prelate of Mt. Kenya East has wronged Kenyans by making unwarranted criticism of his motherland in the presence of foreigners. ${ }^{94}$

In light of the current scholarship, we find it necessary to append a brief typology of Gitari's political sermons in the month of June 1987 as indicated in the table below and to draw some relevant conclusions on the power of the pulpit in the struggle that ensued in Kenya between the prelate and the state. It is also from this basis, that we shall identify and discuss some limitations of the pulpit as the site of political discourses.

Gitari's political sermons preached in June $1987^{95}$

\begin{tabular}{llll}
\hline Date & Place & Title & Book/Text \\
\hline $7 / 6 / 1987$ & Emmanuel & "Harassed and & Matt. 9:35- \\
& Church, Mutira & Helpless" & 38 \\
$14 / 6 / 1987$ & $\begin{array}{l}\text { St. Andrew's } \\
\text { Kabare }\end{array}$ & "Idols of our Times" & Jer. 1:4-10 \\
& St. Peter's, Nyeri & "The Truth is Always & Daniel 6 \\
& Triumphant" & \\
$21 / 6 / 1987$ & Church of the & "All Scripture is & 2 Timothy \\
& Good Samaritan, & Inspired by God" & $3: 16$ to 2 Tim \\
& Kathiga (Mwea) & & $4: 7$ \\
\hline
\end{tabular}

Drawing upon these sermons and the comments that characterised them, one may well ask: How did the political sermons brew a culture of defiance in a polity?

93. Kamaara, "Religion and Socio-Political Change in Kenya”, pp 125-137.

94. Gitari, Let the Bishop Speak, p 56.

95. I have compiled this table from the political sermons from various sermons that are featured in Gitari, Let the Bishop Speak, pp 1-60.The sermons are relevant to the study as they touch on key elements of democracy. 
From the empirical data, it is argued that the "disruptive power" of sermons makes them a force of change. This was underscored by the great publicity attached to Gitari's sermons by the media and the attention they drew from politicians and Christians alike, which demonstrated the propensity of the pulpit as a platform for initiating change. These sermons were also a marked departure from other theological discourses and sites of the struggle. While Africans fought wars in the forests and streets to gain independence, the post-independent wars were being fought from the pulpit by the Church. This was what Robert Press referred to as peaceful resistance, ${ }^{96}$ and it appears to contradict the popularly held view that a liberation model of social engagement is combatant in approach. However, this does not negate the revolutionary aspects of the liberation paradigm.

In Gitari's case, the pulpit offered a platform for the incubation of liberation ideas and transforming them into real action. This worked well for him based on the fact that Kenya is a deeply religious society with about 75 percent of the total population being Christians. ${ }^{97}$ In Kenya the Church holds weekly gatherings; regular church services as well as rural crusades and these are attended by large crowds drawn from all categories of people, including those from remote areas. This implies that more often than not, the thinking and behaviour of Kenyans is inclined to be reflective of the stance taken by the Church. ${ }^{98}$ This means that both Gitari and Moi made public references to the Bible and appealed to God as a symbol of justice during the course of the struggle. For Moi, nyayo was the sure way to salvation for Kenyans who were ethnically divided, while for Gitari the incarnation model was one of the best alternative routes to salvation. Gitari believed that the "nyayo of Jesus" was the sure way to eternal peace, love and unity - unlike the "nyayo of Moi" which was unable to promote national unity, reconciliation and prosperity. The liberative mission of the Church in Kenya, as is the case elsewhere in Africa, could only be realised by following the nyayo of Jesus.

In summary, Gitari's sermons were all based on the importance of adhering to the constitution. His was a call for proper implementation of the law rather than amending the law for the benefit of a few. And even if the law was to be amended, Gitari felt that public participation was very important. He observed succinctly that "the greatest mistake we can make in our national life is to allow important decisions to be made without allowing sufficient time for all those concerned to debate the issues", especially in a country that claimed to be democratic. ${ }^{99}$ This rekindles our memories of the security bill that was hurriedly passed by the eleventh parliament

96. R.M. Press, Peaceful Resistance: Advancing Human Rights and Civil Liberties (Ashgate, Aldershot, 2006).

97. J.M. Gathogo, "David Gitari's Prophetic Ministry in Kenya (1986-1991)”, Studia Historiae Ecclesiasticae, Journal of the Church History Society of Southern Africa, 33, 2 (2007), pp 235-257.

98. Kamaara, "Religion and Socio-Political Change in Kenya", pp 125-137.

99. Interview with Julius Gathogo(digital recording), conducted by Stephen Kapinde, Kenyatta University (Coast Campus), 19 February 2015. 
without public debate. ${ }^{100}$ Gitari would no doubt have had the same prophetic message for the current Kenyan leadership, namely the so-called Jubilee government. 101

\section{Limitations of the pulpit as platform for political discourses}

The vitality of the pulpit as a stable platform for change and the sermons of Gitari at a time when the state had censored nearly everyone and prohibited gatherings of more than three people, proved the legitimacy of the Church in political discourses. ${ }^{102} \mathrm{John}$ Karanja argues that this legitimacy is because sermons were privileged speeches that were less subject to official censorship. ${ }^{103}$ Commenting on this, Galia Sabar cites the Kenyan-based Finance Magazine, of February 1990, saying: "Irrespective of how much we might belittle their social standing, the clerics represent the most cohesively structured, the most firmly organized and the most solidly unified institution in the country." ${ }^{104}$ Although, this observation does not directly give credence to the pulpit as a good platform for political engagement, it nonetheless points to the legitimacy of the actors as agents of social change in society. A critical analysis of political sermons in Kenya, notably those by Gitari, points to the fact that the pulpit is a site of the struggle for social justice. However, politicised sermons are not without some limitations and these variables are discussed below.

Leader characteristics: The impact of any speech or sermon depends on the leader or cleric's ability to connect with the concerns of the people (their socioeconomic and political aspirations) within a specific context. For instance, in his sermon delivered at St. Emmanuel's Church, Mutira, entitled "Harassed and Helpless', Gitari addressed several pertinent issues that were foremost in the minds of the people at that time. Among these were the plight of coffee farmers in the Kirinyaga district; economic inflation; and political harassment of local people by KANU agents. ${ }^{105}$ By identifying with the plight of the people and presenting the gospel in light of the contemporary challenges, Gitari proved to them that Jesus was present

100. “Contentious Security Bill Passed amid Acrimony", Daily Nation, 19 December 2014.

101. The Jubilee government came into power in 2013, following the expiry of the term of the Grand Coalition government. In this historic election, two inductees of the International Criminal Court (ICC), one of whom was Uhuru Muigai Kenyatta (the son of the founding father of the nation, Jomo Kenyatta) and the other William Samoe Ruto (son of a peasant from Kalenjin land) were elected as president and deputy president respectively. In the course of their leadership, they have faced serious challenges of insecurity posed by an Alshabab terrorist group from Somalia. In this context they have taken some radical measures, some of which are in direct contravention of the constitution.

102. Interview with John Mararo, conducted by Stephen Kapinde, 30 January 2015.

103. J.K, Karanja, "The Biblical, Prophetic Ministries of Henry Okullu and David Gitari", Anglican and Episcopal History, 75, 4 (2006), pp 580-604.

104. Finance, Kenya, February, 1990, p 39.

105. Interview with Muriuki, Mararo and Kangangi, conducted by the authors, St. Thomas Cathedral, Kirinyaga, 30 January 2015. 
and relevant in their daily lives. The active involvement of the clergy in social transformation is also confirmed in an interview conducted by Robert Press, when Ndingi Mwana' Nzeki, said: "I speak for them. Then they speak out. Yes they do ... [they respond to] leadership."106 By highlighting the plight of Kenyans, Gitari joined the list of the renowned world leaders such as Rev. Martin Luther King Jr and Desmond Tutu, former Archbishop of the Anglican Church of South Africa, both of whom campaigned against racism and oppression.

Communal support: Another key imperative is the receptiveness of the congregation to accommodate and resonate well with the information provided; to cast their votes according to their consciences; and to actively join the struggle for change. In other words, another necessary ingredient is to engender public empowerment of the people for public participation in the wake of oppression. For instance, in one of the sermons delivered at St. Peter's at Nyeri, the district commissioner, a Mr Mukhalule acknowledged that the sermon was well received, but later - in anticipation of reprisal - he denied having praised the prelate. ${ }^{107}$ Others who openly acknowledged appreciation of Gitari's sermons, such as Isaiah Mathenge, were threatened with suspension from the party. ${ }^{108}$ For the effectiveness of the pulpit, the congregants should understand the message, interpret and relate it to their everyday lives and experiences. Such understanding in terms of civic thinking influences people's attitudes and practices from the local/grassroots level to the national level and thereby gives legitimacy to the need for change.

Media: Coverage of the message by the media and other public entities, for instance civil society in the correct context and without any malice (radio broadcasts, magazines, newsletters and daily newspapers) is also very relevant. Advance notice of an address helps to secure audiences of up to 5000 people. ${ }^{109}$ This was (is) very significant because media coverage unmasked the evils of the regime to national and international partners, legitimising the need for change. Gitari in particular acknowledged the role of the media in the struggle for change and gave credit to the likes of Henry Okullu and Alexander Muge who invited media houses to publicise their sermons. ${ }^{110}$ In a sermon delivered at St. Peter's Nyeri, he prepared an English

106. Interview with Ndingi Mwana' Nzeki, conducted by Robert Press, in Nairobi, on 5 October 2002, accessible at Library of Congress, Washington DC.

107. Gitari, Troubled but Not Destroyed, $\mathrm{p} 219$.

108. "Mathenge and Njururi under Fire but from Different Quarters", Weekly Review Press, 10 July 1987.

109. Sabar-Friedman, "Politics and Power", pp 429-453.

110. In an interview with David Gitari, conducted by Robert Press, Gitari said: "I preached four sermons and I was attacked by politicians after every sermon. That is when the press started noticing me. Before that they had almost ignored me. They were concentrating on [the late Bishop Alexander Muge, and Okullu]. Muge and Okullu were very clever. If they were preaching on Sunday, they would send their sermon to the press on Friday and [mark them] ... "embargoed". But I never sent anything to the press. Accessed with permission from Robert Press, at Library of Congress, Washington DC. 
version of his sermon which he then delivered to the media houses. This was a widely covered sermon which drew a great deal of criticism from the politicians. ${ }^{111}$ On this approach, Sabar Galia argued that the widespread dissemination of the sermons through the media facilitated political debate at a popular level at a time when the government appeared to be trying to inhibit and repress dissent. ${ }^{112}$

Government response: State reaction to the sermons and other biblical expositions depends on the state's attitude to criticism. From the spate of criticism that ensued after Gitari's sermons were delivered there is no doubt that they served their purpose. Gitari's protracted confrontation from the pulpit forced the state to reconsider its approach to criticism. The president probably felt that persistent attacks on the prelate were of little use because after all he felt confident that he enjoyed the support of the majority of Kenyans who were Christians - hence his decision to "let the bishop speak". ${ }^{113}$

From the analysis, it seems Gitari was aware of the four variables discussed above and could mobilise people in advance and identify with their needs. ${ }^{114} \mathrm{He}$ ensured that he sustained the debate on a weekly basis until the government bowed out, either in defiance or by responding positively. ${ }^{115}$ In sum, the prelate with others like Njoya, Muge and Okullu, developed a culture of resistance via the pulpit. Robert Press gives us more insight into this culture by observing:

Individual activists can only do so much in their role as ice-breakers in the reform process. Organizational activists build on their advances but need the presence of members of the public at their events to make a serious bid for reform. The public in turn needs the forum for the activists to express their discontent. Together the resistance sends signals to the regime, the public and international officials and agencies that the demands for change have substance and visible public support. ${ }^{116}$

It appears that the clergy did indeed serve as the precursors to change from the pulpit by acting as 'ice breakers'117 of democratic reform. James Mathenge rightly observes that the Church, mainly the Church of the Province of Kenya (CPK), using its wide networks, acted as a shield to clerics such as Gitari, Okullu and Muge, thereby acquiring the nickname the "Church of the Politics of Kenya". The CPK strengthened the voices of its clerics in the reform process without making use of any political

111. Interview with John Mararo, conducted by Stephen Kapinde, 10April 2015.

112. Sabar-Friedman, "Politics and Power", pp 429-453.

113. Gitari, Let the Bishop Speak, p 56.See also article "Let the Bishop Speak, Says Moi", in Daily Nation,1 July1987.

114. Gitari, "Church and Politics in Kenya", pp 7-17.

115. Interview with Mathenge, conducted by Kapinde, Nairobi, 29 January 2015.

116. Press, Peaceful Resistance: Advancing Human Rights and Civil Liberties.

117. The phrase "ice breakers" is borrowed from Press, "Establishing a Culture of Resistance". 
openings or external opportunities in mainstream civil society. ${ }^{118}$ In particular, Gitari through his moral injunctions, kept the government on its toes and virtually became the "informal mouthpiece" of the CPK alongside Okullu and Muge. ${ }^{119}$ With Church support, the dissenting voices applied pressure on the government and re-defined church/state relations in the subsequent years.

This article does not argue that it was defiance via the pulpit alone that made the government initiate change, but claims that it laid the groundwork for future peaceful resistance. This was evident in the opposition of the Church to the mlolongo (queuing) system of voting and the Church's persistent call for a multi-party dispensation in Kenya. Moreover, defiance from the pulpit prepared the ground for serious political activism in other movements such as the Law Society of Kenya (LSK) under the chairmanship of Paul Muite and vibrant members like Gitobu Imanyara and Martha Karua. Other organisations such as the Forum for the Restoration of Democracy (FORD), a movement founded by Jaramogi Oginga Odinga; the Green Belt Movement under Martha Wangari Maathai; the Justice and Peace Convention (JPC), which was allied to the Justice and Peace Commission of the CPK; and the Justice, Peace, and Reconciliation Commission of the NCCK. It is this concerted effort that led to the repeal of Section 2 (a) of the Constitution in 1991, the precursor to multi-party politics.

\section{Conclusion}

This article has argued that individual agency was the hallmark of the struggle for democratic reform in Kenya between 1986 and 1992. Gitari's critical voice, together with those of other individual clergy activists such as Rev. Timothy Njoya, Ndingi Mwana wa Nzeki and Henry Okullu, cemented the Church's position in the struggle for democratic reform. Their contribution as "ice-breakers" of a reform agenda during this period of political turmoil, or what may rightly be called the "middle ages" of Kenya's democratisation process, is a clear indicator of the Church's involvement in providing the rationale and impetus for the country's effort towards a multi-party political dispensation. However, this is not to downplay the structural or organisational agency and the donor factor as among the fundamental forces behind political reform in Kenya. David Gitari in particular played a significant role in delegitimising the state with his "stinging sermons" on the question of social justice. By relying on the pulpit and the scripture as a tool for liberation, he broke the ground for public defiance and peaceful resistance at a time when deference to a one-party political dispensation was the order of the day.

118. Interview with Mathenge, conducted by Kapinde, Nairobi 29 January 2015.

119. Interview with Mathenge, conducted by Kapinde, Nairobi, 29 January 2015. 


\section{REFERENCES}

Adar, K.G. and Munyae, I.M., "Human Rights Abuse in Kenya under Daniel Arap Moi 1978-2001",African Studies Quarterly, 5, 1 (2001). Available online at http://web.africa.ufl.edu/asq/v5/v5i1a1.htm

Amutabi, M., "Beyond Imperial Presidency in Kenya: Interrogating the Kenyatta, Moi and Kibaki Regimes and Implications for Democracy and Development", Kenya Studies Review, 1 (2009), pp 55-84.

Currie, K. and Ray, L., "State and Class in Kenya: Notes on the Cohesion of the Ruling Class", The Journal of Modern African Studies,22, 4 (1984), pp 559-593.

Gathogo, J.M., “David Gitari's Prophetic Ministry in Kenya (1986-1991)”, Studia Historiae Ecclesiasticae, Journal of the Church History Society of Southern Africa, 33, 2 (2007), pp 235-257.

Gathogo, J.M., Mutira Mission: An African Church Comes of Age in Kirinyaga, Kenya (1912-2012) (Zapf Chancery Publishers, Limuru, 2011).

Gitari, D.M., Let the Bishop Speak (Uzima Press, Nairobi, 1988).

Gitari, D.M., "Church and Politics in Kenya", Transformation, 8, 3 (July/September 1991), pp 7-17.

Gitari, D.M., In Season and out of Season: Sermons to a Nation (Regnum, London, 1996).

Gitari, D.M., Responsible Church Leadership (Acton Publishers, Nairobi, 2005).

Gitari, D.M., Troubled but Not Destroyed: Autobiography of Dr David M. Gitari, Retired Archbishop of the Anglican Church of Kenya (Isaac Nathan Publishing, Woodland Hills, 2014).

Githiga, G.G., The Church as the Bulwark against Authoritarianism (Regnum, Oxford, 2001).

Greenman, J., "Anglican Evangelicals on Personal and Social Ethics", Anglican Theological Review, 94, 2(2012), pp 179-205.

Gutierrez, G., The Power of the Poor in History (Orbis, Maryknoll: NY, 1983).

Kamaara, E., "Religion and Socio-Political Change in Kenya, 1978-2003", in Mugambi, J.N.K. and Kürschner-Pelkann, L. (eds), Church-State Relations: A Challenge for African Christianity (Acton, Nairobi, 2004), pp 125-137.

Karanja, J.K., "The Biblical, Prophetic Ministries of Henry Okullu and David Gitari", Anglican and Episcopal History, 75, 4 (2006), pp 580-604.

Kodia, D.,"The Role of the Church in the Democratization Process in Kenya", International Journal of Innovative Research \& Development, 3, 5 (2014), pp 6469. See also www.ijird.com Accessed 30 March 2015.

Korwa, A.G. and Munyae, I.M., "Human Rights Abuse in Kenya under Daniel arap Moi, 1978-2001", African Studies Quarterly, 5, 1 (2002). See http://web.africa. ufl.edu/asq/v5/v5i1a1.htm Accessed 20 February 2015. 
Lonsdale, J., "Religion and Politics in Kenya", Henry Martyn Lectures, 2004. See http://www.martynmission.cam.ac.uk/CJLonsdale.html

Mati, J.M., "The Power and Limits of Social Movements in Promoting Political and Constitutional Change: The Case of the Ufungamano Initiative in Kenya (19992005)", PhD thesis, University of the Witwatersrand, 2012.

Mbiti, J.S., "Do You Understand What you are Reading? The Bible in African Homes, Schools and Churches", Missionalia, 33, 2 (2005), pp 205-213.

D. Moi, Kenyan African Nationalism, Nyayo Philosophy and Principles (Macmillan, London, 1986).

Mugambi, J.N.K and Frank Kürschner-Pelkann (eds), Church-State Relations: A Challenge for African Christianity (Acton, Nairobi, 2004).

Mutunga, W., Constitution-Making from the Middle: Civil Society and Transition Politics in Kenya, 1992-1997 (Sareat, Nairobi, 1999).

National Church Council of Kenya, A Christian View of Politics in Kenya: Love, Peace, and Unity (Uzima Press, Nairobi, 1983).

O'Donovan, W., Biblical Christianity in Modern Africa (Paternoster Press, Milton Keynes, 2000).

Ogot, B.A., "Transition from Single-Party to Multi-Party Political Systems", in Ogot, B.A. and Ochieng, W. (eds), Decolonization and Independence in Kenya, 1940-1993 (Ohio University Press, Athens,1995).

Oluoch, J., The Christian Political Theology of Rt. Rev. Dr John Henry Okullu, Bishop of the Diocese of Maseno South, of the Anglican Church of Kenya (1929-1999) (Regnum, Oxford, 2003).

Oyugi, W.O., "Uneasy Alliance: Party-State Relations in Kenya”, in Oyugi, W.O. (ed.), Politics and Administration in East Africa (East African Educational Publishers, Nairobi, 1994).

Press, R.M., "Establishing a Culture of Resistance: The Struggle for Human Rights and Democracy in Authoritarian Kenya 1987-2002", PhD thesis, University of Florida, 2004.

Press, R.M., Peaceful Resistance: Advancing Human Rights and Civil Liberties (Ashgate, Aldershot, 2006).

Sabar-Friedman, G., 'Politics' and 'Power' in the Kenyan Public Discourse and Recent Events: The Church of the Province of Kenya", Canadian Journal of African Studies, 29, 3 (1995), pp 429-453.

Sabar-Friedman, G., "Was there No Naboth to Say No?" Using the Pulpit in the Struggle for Democracy", in Knighton, B. (ed.), Religion and Politics in Kenya: Essays in Honor of a Meddlesome Priest (Palgrave Macmillan, New York, 2009).

Sanneh, L., Translating the Message: The Missionary Impact on Culture (Orbis Books, Maryknoll, 1989). 
Throup, D.W. and Hornsby, C., Multi-Party Politics in Kenya: The Kenyatta and Moi States and the Triumph of the System in the 1992 Election (James Currey, Oxford, 1998).

Wright, N.T., After You Believe: Why Christian Character Matters (HarperOne, New York, 2010). 